\title{
Analyzing the problems with the current adoption of IFRS in the companies among India, China, Germany, Russia and Kenya
}

\author{
Robert Mosomi Ombatia ${ }^{a^{*}}$ and Anita Shukla
}

a Research Scholar, Department of Accounting, JRN Rajasthan Vidhyapeeth University, Udaipur-Rajasthan, India ${ }^{b}$ Head Department of Accounting, JRN Rajasthan Vidhyapeeth University, Udaipur-Rajasthan, India

\begin{tabular}{|c|c|}
\hline CHR O N I C L E & A B S T R A C T \\
\hline $\begin{array}{l}\text { Article history: } \\
\text { Received January 9, } 2017 \\
\text { Received in revised format } \\
\text { January } 112017 \\
\text { Accepted March } 282017 \\
\text { Available online } \\
\text { March } 282017 \\
\text { Keywords: } \\
\text { IFRS } \\
\text { IFRS adoption } \\
\text { Problems of adoption } \\
\text { Company related problems } \\
\text { Investor's related problems and } \\
\text { government agency related } \\
\text { problems }\end{array}$ & $\begin{array}{l}\text { Accounting information provides past and current financial information of an economic unit } \\
\text { for business managers, potential investors, and other interested parties. Internally generated } \\
\text { accounting information helps business managers with planning, controlling, and making } \\
\text { decisions referred to as managerial accounting information. However, if the companies, which } \\
\text { have adopted International Financial Reporting Standards (IFRS) globally, cannot generate the } \\
\text { same information then the accounting practices need to be improved. For this purpose, the } \\
\text { current study was performed with the objectives of measuring relationship between } \\
\text { profitability and market capitalization and to analyze the challenges faced by listed firms of } \\
\text { various countries in association with the implementation of IFRS. For this purpose, } 15 \\
\text { companies were selected from } 5 \text { countries including India, China, Germany, Russia and Kenya. } \\
\text { The secondary data regarding the correlation between profitability and market capitalization } \\
\text { were analyzed to calculate the correlations. The primary data regarding the managers } \\
\text { perception were analyzed with multiple regression method using SPSS-19 software to find out } \\
\text { the company related variables, investors' related variables and government agency related } \\
\text { variables responsible for problems in the current adoption of IFRS. }\end{array}$ \\
\hline
\end{tabular}

\section{Introduction}

Accounting information provides past and current financial information of an economic unit for business managers, potential investors, and other interested parties. Internally generated accounting information helps business managers with planning, controlling, and making decisions referred to as managerial accounting information. This information is used primarily by internal users, and most of it is not required to be presented publically on the company's financial statements. On the other hand, financial accounting information is targeted towards external users who have no control over the actual preparation of the reports and do not have access to the underlying details. Therefore, the ability to understand and compare financial reports directly depends on standardization of the principles and practices that are used to prepare the reports. To ensure confidence in financial information,

* Corresponding author. Tel: +91 9001810380

E-mail address: ombatirobert@yahoo.in (R. M. Ombati) 
professional organizations were established to bring consistency and structure to financial reporting. To promulgate accounting principles internationally, the London-based International Accounting Standards Board (IASB) was established as a privately-funded, independent, accounting standardsetter. It consists of 15 full-time members, including members from the United States, and works towards developing "a single set of high quality, understandable, enforceable, and globally accepted financial reporting standards based upon clearly articulated principles." (About the IFRS). This single set of high-quality standards is stated as the International Financial Reporting Standards (IFRS) and is becoming the global standard for the preparation of public company financial statements. The IFRS Foundation oversees and approves all accounting standards created by the IASB.

With many companies expanding to global markets, the need for global transparency among financial statements is becoming more and more important. Currently, there is no official set of accounting standards required for all international public companies. This approach has worked for many years, but it is becoming unfavourable as more companies seek to operate in foreign markets and raise capital from international creditors and investors. In its present state, financial information from certain countries has almost no global comparability, causing many potential investors to refrain from investing in these companies due to the lack of confidence in or understanding of the financial information used in that country. This underlines the increasing importance of global comparability among financial statements. To achieve this goal, many countries have already adopted IFRS as their required method of financial reporting. Since 2001, over 100 countries have required or permitted the use of IFRS, and all remaining major economies have established time lines to converge with or adopt IFRS in the near future. While the United States already permits the use of IFRS for foreign issuers and subsidiaries, it has not fully adopted IFRS as the authoritative set of accounting standards.

IFRS clearly represents a global financial reporting as a benchmark and many countries have by this time adopted IFRS standard for listed home companies too. With the recent issuance of IFRS for Small and Medium Enterprises, a stand-alone set of standards for private entities that do not have public accountability, the global reach of the IASB is further enhanced. However, due to interpretational alterations if these standards will not be used uniformly by various countries of the world, then effectiveness of the common medium will be lost.

Due to several reasons, including the highly publicized corporate debacles such as Enron in the United States, the global preference of most countries has now been clearly in favour of IFRS as the most acceptable set of international accounting and financial reporting standards worldwide.

IFRS has been adopted by around 150 countries of the world now and few more expected to adopt IFRS in the coming years, it could possibly count as an Esperanto in the area of global accounting. By 2016, the world of accounting may be rejoicing and celebrate under a strong common banner of IFRS.

The IFRS have provided a strong foundations from 1973 when representatives of the professional accounting bodies of world including Australia, Canada, France, Germany, the United Kingdom, Ireland and the US have made a committee called International Accounting Standards Committee (IASC) who wish to remove political jurisdictions in accounting area. In 1975, the IASC pronounced its first International Accounting Standard (IAS). Since then the IASC issued a total of 41 IAS until it was restructured into the International Accounting Standard Board (IASB) in 2001. The IASB has pronounced a total of Fifteen (15) International Financial Reporting Standards (IFRS) as on 2015. A major task of the IASB is to cooperate with national accounting standard setting bodies to achieve harmonization in accounting standards around the world. Nowadays, the IAS and IFRS are widely accepted and have become one of the most prevalent accounting standards around the world.

Some countries-Australia, and New Zealand-have changed their local standards into new standards that are virtually similar to IFRS. Other countries, for example, Singapore, India, Malaysia, Thailand, and others, have changed most parts of local standards that are equivalent to IFRS. 
Economic activities such as investments, mergers and acquisitions, and diversifications are key activities of development, survival and sustainability. Companies are in competition at global level.

The main purpose of this research paper is to investigate how the process of IFRS adoption for the national accounting system develops in these countries. The additional purposes are to show how countries work with the reformation of their accounting system, how the national historic and economic development affected accounting and financial reporting, as well as define obstacles and problems which the countries in general and separate companies, in particular, have come across in connection with IFRS implementation. The study might be interesting for those who are interested in international questions and international accounting. It might also be useful to other countries whose companies have subsidiaries in countries of study and other parties who operate internationally. The objectives of this paper are as follows,

1. To measure the relation between profitability and Market capitalization amongst IFRS adopted selected companies.

2. To analyze the challenges faced by Listed Firms of various Countries in relation to implementation of International Financial Reporting Standards.

\section{Review of the literature}

The major difference between IFRS and National GAAP is that IFRS requires more discretion and National GAAP is much more detailed (Hail et al., 2014). For the median company, profits jumped by $11 \%$. Thus, IFRS incorporates the value judgment of an accountant in its financial report. These value judgments can be easily influenced by incentives a company may have, causing a variety of ways to implement IFRS. This further interferes with creating a global standard. One of the disadvantages of the Country switching to IFRS in its current state is lower quality and less enforcement. Another disadvantage of adopting IFRS is that the Country's power over accounting would diminish. While switching to IFRS may "signal willingness by the country to cooperate internationally" (Hail, 2014), it would also give "monopoly status to London-based IASB" (Hail et al., 2014). This could pose several problems. First, the IASB would be a step closer to being a potentially dangerous monopolist. Since a monopolist faces no competition, IASB standards could slip and would not be corrected. In order to prevent such an event from happening, the infrastructure of the IASB should be evaluated as part of the IFRS convergence project. The last disadvantage of switching to IFRS is that the IASB does not have a stable source of funding (Yoon, 2009). Its finances derive primarily from "corporate contributions from various countries" (Yoon, 2009). For example, in October 2008, IASB had bowed to pressure from European regulators on the issue of fair value accounting. It had allowed a certain transfer of assets which FASB only allowed in "rare circumstances" (Yoon, 2009). However, that would not be the last time when European and other governments would continuously try to interfere. According to Ball (2006) "Accounting in shaped by economic and political forces. It follows that increased worldwide integration of both markets and politics (driven by reductions in communications and information processing costs) makes increased integration of financial reporting standards and practice almost inevitable" (Kamwenji, 2014; Ball, 2006). However, most market and political forces may stay local for the future, so it is not clear how much convergence in actual financial reporting practice may or should happen (Kamwenji, 2014; Ball, 2006). In addition, there is a little evidence to build an evaluation of the advantages as well as disadvantages of uniform accounting regulation. Vašiček et al. (2010) revealed that in conditions of globalization and recession which has affected in recent time almost entire world, the management of public sector, but also and business sector is faced with more additional requirements and efforts for quality management and for more rational and efficient spending of resources. Under such conditions, the process of convergence of financial reporting in the public sector to the practice of business sector is present in many countries. The process of convergence of financial reporting of public sector to the practice of business sector includes the adaptation of IFRS in the public sector. Assumption of convergence of financial reporting in the public sector with the business sector reporting is based on the application of International Public Sector Accounting Standards (IPSAS) which are approaching and are based on IAS/ IFRS. Implementation of IFRS in the 
public sector implies application of accrual basis of accounting. Chand et al. (2015) explained that diverse complications and controversial issues in the adoption of IFRS for Small and Medium-sized Enterprises (SMEs) have been reported by many jurisdictions, prompting them not to adopt this set of standards. Conversely many jurisdictions have adopted or are in the process of adopting IFRS for SMEs. Hail et al. (2014) examined changes in firms' dividend pay-outs following an exogenous shock to the information asymmetry problem between managers and investors. Agency theories predict a decrease in dividend payments to the extent that improved public information lowers managers' need to convey their commitment to avoid overinvestment via costly dividend pay-outs. Conversely, dividends could increase if minority investors are in a better position to extract cash dividends. They tested these predictions by analysing the dividend payment behaviour of a global sample of firms around the mandatory adoption of IFRS and the initial enforcement of new insider trading laws. Both events served as proxies for a general improvement of the information environment and, hence, the corporate governance structure in the economy. They reported that, following the two events, firms are less likely to pay (increase) dividends, but more likely to cut (stop) such payments. The changes occur around the time of the informational shock, and only in countries and for firms subject to the regulatory change.

Evans et al. (2015) investigated the implications of language translation in accounting. They also examined the ideological, cultural, legal, and political consequences of translation and reported that the ambiguity inherent in translation was, on the one hand, relevant for the translation of accounting principles and could contribute to accounting convergence. They reported that it has the potential to be exploited in ideologically or pragmatically motivated distortions in the implementation of accounting regulation. They further argued that the importance of translation in accounting was underestimated or disregarded, inter alia because it has limited effect on the culturally and economically most dominant stakeholders. According to Nobes and Zeff (2008) international financial reporting standards (IFRS) have been adopted in many countries, at least for the consolidated reporting of listed companies. However, in most cases, what the rules need is some national or supranational version of IFRS. This might create problems for investor confidence and comparability. They examined what companies and auditors report concerning compliance with IFRS, focusing on the first full year of IFRS reporting by companies in the stock market indices of four major European countries and Australia. They find that, even when firms were complying with IFRS, they were generally not saying so, which appears to miss part of the point of the 35-year project on international harmonization. In a small number of cases, auditors provided dual reports: on full IFRS in addition to the mandated reference to national GAAP where the latter corresponds with full IFRS.

According to Albu et al. (2010, 2011) IFRS implementation is of a great interest for researchers, practitioners and regulatory bodies. The IFRS for Small and Medium-sized Entities (SMEs) was issued in July 2009 and currently strategies are needed for the implementation of this standard. Albu et al. $(2010,2011)$ discussed the results obtained in Europe concerning the implementation of the IFRS for SMEs and the implications of a possible implementation in Romania. Heald and Georgiou (2011) evaluated Public-Private Partnerships (PPP) accounting practices and the related financial accounting and reporting requirements. Chen et al. (2010) reviewed previous studies on the effect of International Financial Reporting Standards (IFRS) on accounting quality often have difficulties to control for confounding factors on accounting quality. They found that the majority of accounting quality indicators improved after IFRS adoption in the EU. That is, there is less of managing earnings toward a target, a lower magnitude of absolute discretionary accruals, and higher accruals quality. But our results also show that firms engage in more earnings smoothing and recognize large losses in a less timely manner in post-IFRS periods. The increasing number of companies in the global scenario use IFRS today. The process of implementation of IFRS varies on account of Historical Political, Economic and Legal differences in the countries in question. IFRS implementation is a comprehensive process that might significantly affect a country's infrastructure and involve many different groups/parties. All 
of the parties involved both at state and private levels are forced to undertake big changes, which result in increased workload for everyone concerned.

\section{Research methodology}

The methodology used for the current research includes the following points:

3.1 Data Collection: A self-administered questionnaire was used to collect the data from the respondents of the selected countries. This sampling method were used which allowed respondents to complete a survey instrument on their own, which has the benefits of eliminating interviewer bias, the ability to reach large research populations and attain an acceptable response rate. The questionnaire was send by mail to the respondents and they were called to provide their views on the various problems they faced.

3.2 Data Source: This research work is in the form of empirical and exploratory study for which the information was gathered from the Primary and Secondary sources. The primary data were collected from a structured questionnaire including all the areas of the problem which were classified into the company related, investors related and government agency related problems. The secondary data related with the profitability and market capitalisation were gathered from the annual reports of the companies. Other sources like various documents, Industry Reports, and other publication were also used for collection of secondary data.

3.3 Type of sample: The sample includes Auditors, Accountants and Managers of selected countries including India, China, Germany, Russia and Kenya. The 3 companies from each country were selected for the current study.

3.4 Universe of study: The total numbers of financial professionals working in the selected countries are included in the universe of the current study but due to various limitations sampling method were used to conduct current study.

3.5 Sample size: For the purpose of current study a health sample of 200 financial professionals working in the selected companies were selected on the basis of the convenient sampling method.

3.6 Data Analysis Tools: For the current study the data were first meticulously examined in terms of correctness and completeness. The statistical techniques that were used for data analysis include correlation, ANOVA and multiple regression analysis.

\subsection{Data Analysis}

The data related with the study were collected from 15 companies. The accounting standards used by selected companies were presented in this section in table-1 as under:

Table 1

Accounting standards used by selected companies

\begin{tabular}{lll}
\hline Country & Company & Used Standards \\
\hline Indian Companies & Infosys ltd & IFRS, Indian GAAP (Ind AS) \\
& Wipro ltd & IFRS, Indian GAAP (Ind AS) \\
& Dr. Reddy's Laboratory & IFRS, Indian GAAP (Ind AS) \\
\hline Russian Companies & Intercos-IV Ltd. & IFRS, RSA \\
& Metrocom Ltd. & IFRS, RSA \\
& JSC Lenenergo & IFRS, RSA \\
\hline Chinese Companies & Chang Chun Faw Sihuan automobile Co. Ltd & IFRS \\
& Eurasia Group Co. Ltd & IFRS \\
& Yatai Group Co. Ltd & IFRS \\
\hline Kenyan Companies & Eco-bank Kenya Limited & IFRS \& IAS \\
& Kenya Port Authority & IFRS \& IAS \\
& Safaricom Limited & IFRS \& IAS \\
\hline Germany Companies & Allianz Worldwide & IFRS \& HGB Rules \\
& DaimlerChrysler & IFRS \& HGB Rules \\
& Deutsche Bank Group & IFRS \& HGB Rules \\
\hline
\end{tabular}


The distribution of respondents as per their Primary work has shown in Table 2 and Fig. 1 as under:

Table 2

Primary work of the Operating companies

\begin{tabular}{lcc}
\hline & Frequency & Percent \\
\hline Investor Relation & 8 & $4.0 \%$ \\
IT & 50 & $25.0 \%$ \\
Operation, Finance \& Business & 38 & $19.0 \%$ \\
Treasury & 104 & $52.0 \%$ \\
\hline Total & 200 & $100.0 \%$ \\
\hline
\end{tabular}

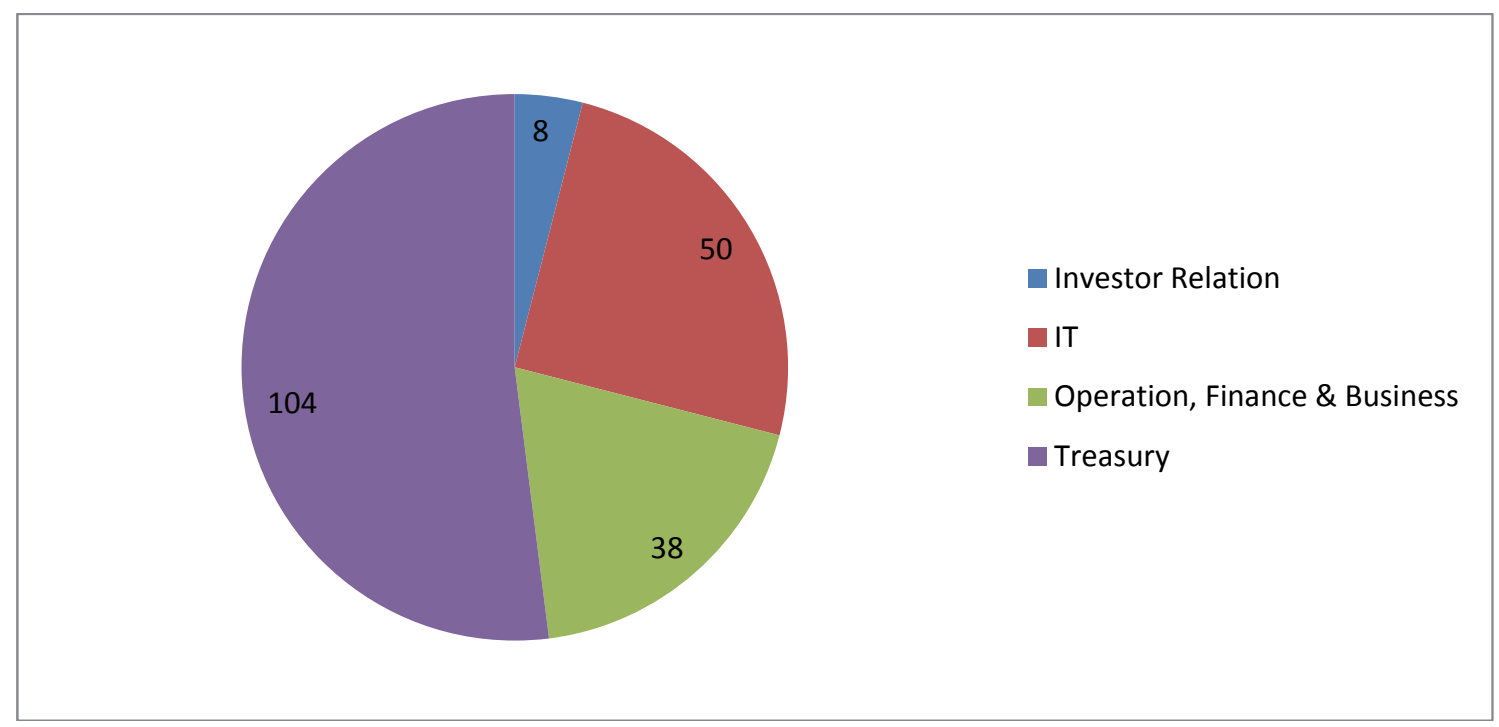

Fig. 1. Primary work of the Operating companies

Table 2 and Fig. 1 have shown that the 52 percent of the respondents were working in the companies having primary function as treasury followed by IT ( 25 percent) and others ( 23 percent).

As per the first objective of the study the correlation between the profit and market-capitalization of the selected companies were calculated and presented in Table 3 as under:

Table 3

Correlation between Profitability and market capitalisation in selected companies

\begin{tabular}{llcc}
\hline & & Profit & Market Capitalization \\
\hline profit & Pearson Correlation & 1 & $.975^{* *}$ \\
& Sig. (2-tailed) & & .000 \\
& $\mathrm{~N}$ & 15 & 15 \\
\hline \multirow{2}{*}{ Market Capitalization } & Pearson Correlation & $.975^{* *}$ & 1 \\
& Sig. (2-tailed) & .000 & \\
& $\mathrm{~N}$ & 15 & 15 \\
\hline **. Correlation is significant at the 0.01 level (2-tailed). & &
\end{tabular}

The results of Table 3 reveal a high degree of positive correlation between profit and market capitalisation in selected companies. This means that the correlation between the profit and market capitalisation (value of the share) have found more in the selected companies because of the IFRS adoption. The views of the respondents of the 5 countries were analysed to know the problems exists in the companies of selected countries. For this purpose the data were collected from the respondents of 15 companies. The profile of the respondents was presented first in Table 4 as follows, 
Table 4

Respondents' profile

\begin{tabular}{|c|c|c|}
\hline & Count & Percent \\
\hline \multicolumn{3}{|l|}{ Gender } \\
\hline Male & 148 & $74.0 \%$ \\
\hline Female & 52 & $26.0 \%$ \\
\hline \multicolumn{3}{|l|}{ Age } \\
\hline Below 25 & 0 & $0 \%$ \\
\hline 25-35 & 12 & $6 \%$ \\
\hline $35-45$ & 120 & $60 \%$ \\
\hline $45 \&$ above & 68 & $34 \%$ \\
\hline \multicolumn{3}{|l|}{ Occupation } \\
\hline Auditor & 58 & $29.0 \%$ \\
\hline Accountant & 86 & $43.0 \%$ \\
\hline Managers & 56 & $28.0 \%$ \\
\hline \multicolumn{3}{|l|}{ Education } \\
\hline Graduation & 4 & $2.0 \%$ \\
\hline Post Graduate & 42 & $21.0 \%$ \\
\hline CA & 56 & $28.0 \%$ \\
\hline CS & 34 & $17.0 \%$ \\
\hline ICWAI & 36 & $18.0 \%$ \\
\hline CPA & 28 & $14.0 \%$ \\
\hline \multicolumn{3}{|l|}{ Experience } \\
\hline Less than 5 years & 30 & $15.0 \%$ \\
\hline 5 to 15 years & 108 & $54.0 \%$ \\
\hline More than 15 years & 62 & $31.0 \%$ \\
\hline \multicolumn{3}{|l|}{ Native Country } \\
\hline India & 66 & $33.0 \%$ \\
\hline China & 22 & $11.0 \%$ \\
\hline Germany & 26 & $13.0 \%$ \\
\hline Russia & 36 & $18.0 \%$ \\
\hline Kenya & 50 & $25.0 \%$ \\
\hline
\end{tabular}

The respondents were from the different companies and thus the respondents selected for the current study were shown in Table 5 as under:

\section{Table 5}

Company-Wise distribution of respondents

\begin{tabular}{llcc}
\hline & Frequency & Percent \\
\hline Infosys & 40 & 20.0 \\
Wipro & 10 & 5.0 \\
Dr. Reddy's & 16 & 8.0 \\
INTERCOS & 12 & 6.0 \\
Metrocom & 10 & 5.0 & 7.0 \\
JSC & 14 & 4.0 \\
Chang chug & 8 & 4.0 \\
Eurasia & 8 & 3.0 \\
Yatai & 6 & 6.0 \\
Eco- bank & 12 & 10.0 \\
KPA & 20 & 9.0 \\
Safaricom & 18 & 3.0 \\
Allianz & 6 & 4.0 \\
\hline Daimler & 8 & 6.0 \\
\hline Deutsche & 12 & $\mathbf{1 0 0 . 0}$ \\
\hline
\end{tabular}




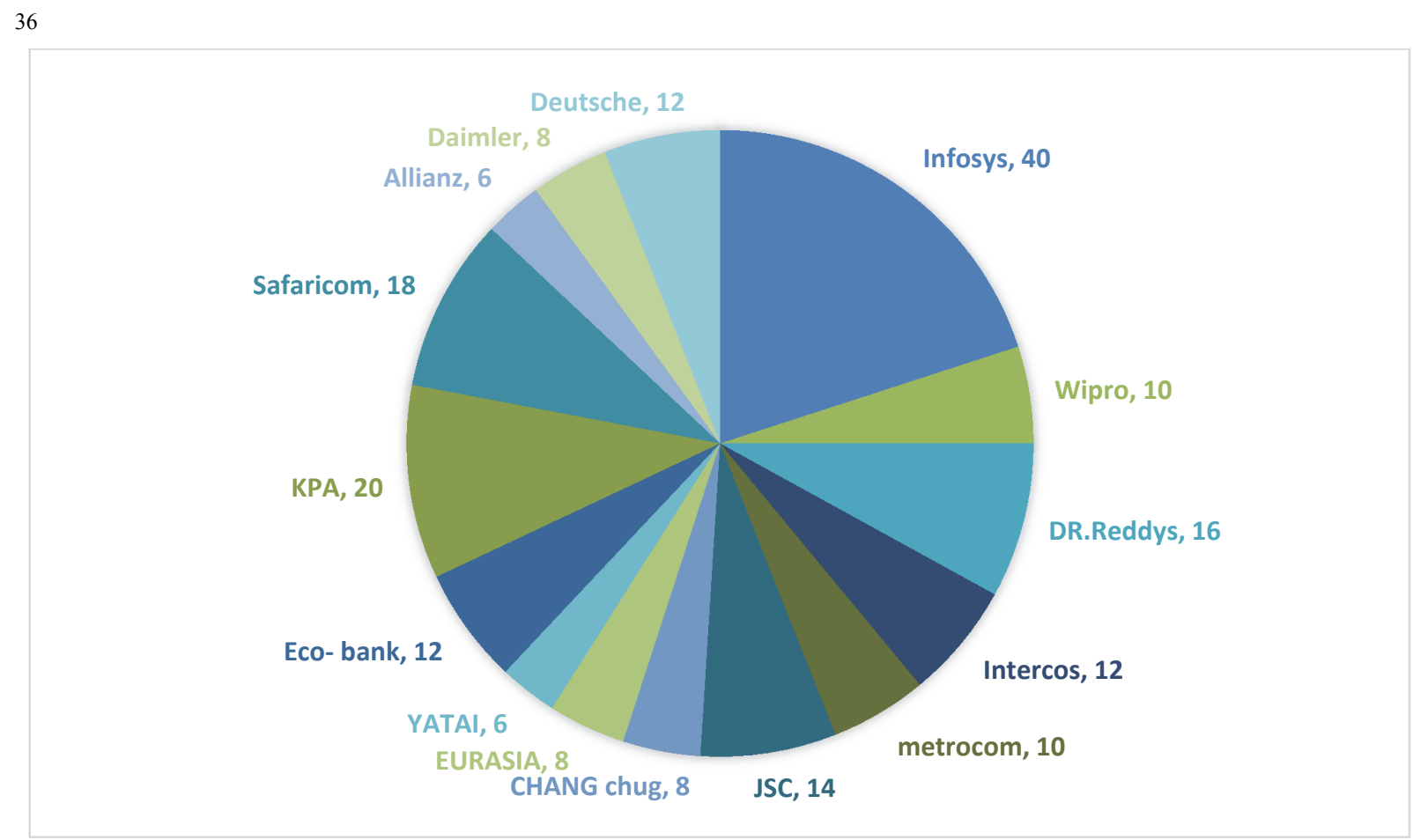

Fig. 2. Company wise distribution of respondents

As per the objective of the study the agreement of the respondents related with the company related problems on IFRS implementation policies were checked and following hypotheses was developed:

$\mathrm{H}_{1(\mathrm{a})}$ : The attributes configuring IFRS implementation on the company related problems significantly influence the problems of IFRS adoption.

$\mathrm{H}_{1(\mathrm{~b})}$ : The attributes configuring IFRS implementation on the investors related problems significantly influence the problems of IFRS adoption.

$\mathrm{H}_{1(\mathrm{c})}$ : The attributes configuring IFRS implementation on the Government related problems significantly influence the problems of IFRS adoption.

To identify key variables of their satisfaction multivariate regression analysis has been used with SPSS19 software and results were shown in Table 6 as follows,

Table 6

Multiple regression analysis of IFRS Implementation

\begin{tabular}{|c|c|c|c|c|c|c|c|c|c|}
\hline Variable & Constant & $\begin{array}{l}\text { Std. Error of the } \\
\text { Estimate }\end{array}$ & t-Statistics & p-value & $\mathrm{R} 2$ & Tolerance & ANOVA & Sig. & Result \\
\hline $\begin{array}{l}\text { Company related } \\
\text { Variables }\end{array}$ & 4.603 & .723 & 6.368 & .000 & .389 & 0.746 & 19.070 & $.000 \mathrm{~g}$ & $\mathrm{H} 0$ rejected \\
\hline $\begin{array}{l}\text { Investors related } \\
\text { variables }\end{array}$ & 2.691 & .230 & 11.699 & .000 & .020 & 0.969 & 4.964 & $.027^{\mathrm{a}}$ & $\mathrm{H} 0$ rejected \\
\hline $\begin{array}{l}\text { Government agency } \\
\text { related variables }\end{array}$ & 6.717 & .578 & 11.630 & .000 & .402 & 0.638 & 34.389 & $.000^{\mathrm{d}}$ & $\mathrm{H} 0$ rejected \\
\hline
\end{tabular}

\section{Discussion and analysis}

\subsection{Result of company related problems}

The final regression model with 7 independent variables (CR_9E, CR_6E, CR_4E, CR_7E, CR_2E, CR_3E and CR_1E) explains almost $38.9 \%$ of the variance of company related variables on problems 
related with IFRS adoption. Also, the standard errors of the estimate have been reduced to .723, which means that at $95 \%$ level, the margin of errors for any predicted value of problems related with IFRS adoption can be calculated as \pm 1.42884 ( $1.96 \mathrm{X} 0.723)$. The seven regression coefficients, plus the constraints are significant at 0.05 levels. The impact of multi collinearity in the 7 variables is not substantial. They all have the tolerance value less than 0.746 , indicating that only over $26.4 \%$ of the variance is accounted for by the other variables in the equation.

The ANOVA analysis provides the statistical test for overall model fit in terms of F Ratio. The total sum of squares (32.000) is the squared error that would happen if the means of various factors of problems from IFRS have been used to predict the dependent variable. By using the values of CR_9E, CR 6E，CR 4E，CR_7E，CR_2E，CR_3E and CR 1E the errors can be reduced by $41 . \overline{0} 1 \%$ $(13.124 / 32.000)$. This reduction is deemed statistically significant with the F ratio of 19.070 and significance at level of 0.003 . With the above analysis it can be concluded that the variables i.e., CR_9E, CR_6E, CR_4E, CR_7E, CR_2E, CR_3E and CR_1E could explain the problems from implementation of IFRS in selected companies.

\subsection{Result of investor's related variables}

The final Regression model with only one independent variable (IR_3E) explains almost $2 \%$ of the variance of investor's related variables on problems related with IFRS adoption. Also, the standard errors of the estimate has been reduced to .39707 , which means that at $95 \%$ level, the margin of errors for any predicted value of problems related with IFRS adoption can be calculated as \pm 0.7782572 (1.96 $\mathrm{X}$ 0.39707). The one regression coefficients, plus the constraints are significant at 0.05 levels. The impact of multi collinearity in the 1 variable is not substantial. They all have the tolerance value less than 0.969 , indicating that only over $3.1 \%$ of the variance is accounted for by the other variables in the equation.

The ANOVA analysis provides the statistical test for overall model fit in terms of F Ratio. The total sum of squares (32.000) is the squared error that would happen if the means of various factors of problems from IFRS have been used to predict the dependent variable. By using the values of IR_3E the errors can be reduced by $2.44 \%(0.783 / 32.000)$. This reduction is deemed statistically significant with the F ratio of 4.964 and significance at level of 0.027 . With the above analysis it can be concluded that one variables i.e., IR_3E could explain the problems from implementation of IFRS in selected companies.

\subsection{Result related Government agency variables}

The final regression model with only four independent variables (Govt_9E, Govt_4E, Govt_6E and Govt_3E) explains almost $40.2 \%$ of the variance of government agency related variables on problems related with IFRS adoption. Also, the standard errors of the estimate has been reduced to .31020 , which means that at $95 \%$ level, the margin of errors for any predicted value of problems related with IFRS adoption can be calculated as \pm 0.607992 (1.96 X .31020). The four regression coefficients, plus the constraints are significant at 0.05 levels. The impact of multi collinearity in the 4 variables is not substantial. They all have the tolerance value less than 0.638 , indicating that only over $36.2 \%$ of the variance is accounted for by the other variables in the equation.

The ANOVA analysis provides the statistical test for overall model fit in terms of F Ratio. The total sum of squares (32.000) is the squared error that would happen if the means of various factors of problems from IFRS have been used to predict the dependent variable. By using the values of Govt_9E, Govt_4E, Govt_6E and Govt_3E the errors can be reduced by $41.36 \%(13.236 / 32.000)$. This reduction is deemed statistically significant with the F ratio of 34.389 and significance at level of 0.000 . With the above analysis it can be concluded that four variables i.e., Govt_9E, Govt_4E, Govt_6E and Govt_3E could explain the problems from the implementation of IFRS in selected companies. 


\section{Conclusion}

With the above analysis, it can be concluded that there was a high degree of positive correlation between profit and market capitalization in selected companies. This means that the correlation between the profit and market capitalization (value of the share) was more in the selected companies because of the IFRS adoption.

We may also conclude that seven variables i.e., CR_9E, CR_6E, CR_4E, CR_7E, CR_2E, CR_3E and CR_1E could explain the company related problems from the implementation of IFRS in selected companies. For instance, IR_3E explained the investors' related problems and four variables i.e., Govt_9E, Govt_4E, Govt_6E and Govt_3E explained the government agency related problems from the implementation of IFRS in selected companies.

\section{Acknowledgement}

The authors would like to thank the anonymous referees for constructive comments on earlier version of this paper.

\section{References}

Albu, C. N., Albu, N., Fekete, S., \& Cuzdriorean, V. D. (2010, October). IFRS for SMEs in EuropeLessons for a Possible Implementation in Romania. In Proceedings of the 5th WSEAS International Conference on Economy and Management Transformation (Vol. 2, pp. 659-663).

Albu, C. N., Albu, N., \& Fekete, S. (2011). The context of the possible IFRS for SMEs implementation in Romania: an exploratory study. Available at SSRN: http://ssrn.com/abstract=1769991

Ball, R. (2006). International Financial Reporting Standards (IFRS): pros and cons for investors. Accounting and business research, 36(sup1), 5-27.

Chand, P., Patel, A., \& White, M. (2015). Adopting international financial reporting standards for small and medium-sized enterprises. Australian Accounting Review, 25(2), 139-154.

Chen, H., Tang, Q., Jiang, Y., \& Lin, Z. (2010). The role of international financial reporting standards in accounting quality: Evidence from the European Union. Journal of International Financial Management \& Accounting, 21(3), 220-278.

Evans, L., Baskerville, R., \& Nara, K. (2015). Colliding worlds: Issues relating to language translation in accounting and some lessons from other disciplines. Abacus, 51(1), 1-36.

Hail, L., Tahoun, A., \& Wang, C. (2014). Dividend payouts and information shocks. Journal of Accounting Research, 52(2), 403-456.

Heald, D., \& Georgiou, G. (2011). The Substance of Accounting for Public-Private Partnerships. Financial Accountability \& Management, 27(2), 217-247.

Kamwenji, J. M. (2014). The effect of adoption of international financial reporting standards on the quality of accounting information of deposit taking Saccos in Nairobi county (Doctoral dissertation, University of Nairobi).

Nobes, C. W., \& Zeff, S. A. (2008). Auditors' affirmations of compliance with IFRS around the world: An exploratory study. Accounting Perspectives, 7(4), 279-292.

Vašiček, V., Dragija, M., \& Hladika, M. (2010, January). Convergence of financial reporting in the public sector to the practice of business sector. In 5th International Conference of the School of Economics and Business.

Yoon, N. (2009). Advantages and Disadvantages of switching from US GAAP to IFRS. 


\section{(Part-A) PERSONAL INFORMATION}

Name:

Age:

Gender: Male $\square$ Female $\square$

Educational Qualification:

Graduation

Post-Graduation

Chartered Accountant

Company Secretory

Cost and Works Accountant

Chartered Professional Accountants

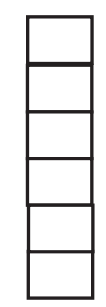

Working as: Auditor

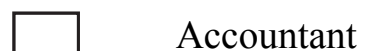

Accountant

Manager

Native Country:

India

China

Germany

Russia

Kenya

Name of Company in which you are working:

Please indicate your primary area of work:

Financial Reporting $\square \quad$ Investor Relations

Management Accounting $\square$ Operations, Finance, Business

IT $\square$

Other (please specify)

\section{Work Experience:}

Less than 5 years 


\section{(Part-B) IFRS INFORMATION}

\section{Have you faced any problem with the Current Adoption of IFRS in your company?}

(Please Tick $[\sqrt{ }]$ the appropriate box)
Always
Every time
Sometime
No opinion
Never

Please Display your degree of agreement/disagreement about Problems of working with IFRS

(Please Tick $[\sqrt{ }]$ the appropriate box)

\begin{tabular}{|c|c|c|c|c|c|c|c|}
\hline $\begin{array}{l}\text { S. } \\
\text { No. }\end{array}$ & Questions & $\begin{array}{l}\text { SPSS } \\
\text { Name }\end{array}$ & 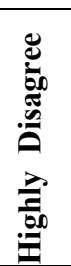 & 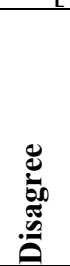 & 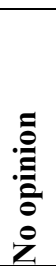 & 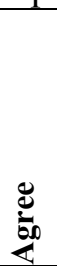 & 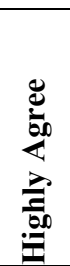 \\
\hline \multicolumn{8}{|c|}{ COMPANY RELATED } \\
\hline 1 & Lack of professionals & CR_1E & & & & & \\
\hline 2 & New format & CR_2E & & & & & \\
\hline 3 & Educational awareness is less & CR_3E & & & & & \\
\hline 4 & Improvement and increase in cost & CR_4E & & & & & \\
\hline 5 & Trade-flows and investment related problems & CR_5E & & & & & \\
\hline 6 & Revenue recognition & CR_6E & & & & & \\
\hline 7 & Difference in inventory valuation & CR_7E & & & & & \\
\hline 8 & Difference in recognising the assets & CR_8E & & & & & \\
\hline 9 & Absence of training & CR_9E & & & & & \\
\hline \multicolumn{8}{|c|}{ INVESTORS RELATED } \\
\hline 10 & Lack of understanding & IR_1E & & & & & \\
\hline 11 & Lack of clarity & IR_2E & & & & & \\
\hline 12 & Way of disclosing Financial information & IR_3E & & & & & \\
\hline \multicolumn{8}{|c|}{ GOVERNMENT AGENCY RELATED } \\
\hline 13 & Taxation issues & Govt_1E & & & & & \\
\hline 14 & Format of adoption & Govt_2E & & & & & \\
\hline 15 & Less availability professionals & Govt_3E & & & & & \\
\hline 16 & Data Comparability & Govt_4E & & & & & \\
\hline 17 & Transparency & Govt_5E & & & & & \\
\hline 18 & Data Quality & Govt_6E & & & & & \\
\hline 19 & Computerisation & Govt_7E & & & & & \\
\hline 20 & Corporate Law related & Govt_8E & & & & & \\
\hline 21 & Fair Value Accounting & Govt_9E & & & & & \\
\hline
\end{tabular}

Please provide the suggestions for implementation of IFRS in various companies? Kindly Specify. 